\title{
Unirismo y Pluma Libre. Expresiones y transformaciones de la prensa gaitanista de los años $30^{*}$
}

\author{
Unirismo and Pluma Libre. \\ Expressions and Transformations of Gaitanist \\ Newspapers of 1930's
}

\section{Carlos Andrés Charry-Joya ${ }^{1}$}

Profesor de Carrera Asociado, Escuela de Ciencias Humanas, Universidad del Rosario, Bogotá, Colombia carlosa.charry@urosario.edu.co

https://orcid.org/0000-0002-2686-7716

Recibido: $24-10-18$

Aprobado: 29-05-19

\footnotetext{
* El siguiente artículo es una versión ampliada y revisada de algunos de los apartes de la tesis doctoral en sociología elaborada por el autor. 


\section{Resumen}

El objetivo central del presente artículo es analizar los contenidos y transformaciones de los periódicos gaitanistas Unirismo y Pluma Libre. Para el logro de tal objetivo, la metodología desarrollada parte de una aproximación a las estrategias discursivas a través de las cuales los integrantes del naciente movimiento gaitanista dieron forma a un conjunto de opiniones y de acciones políticas. La interpretación que se hace parte de la conceptualización de tales medios como empresarios cognitivos. Como conclusión general del análisis que se propone, se identifican las dificultades organizativas e ideológicas que vivió el movimiento gaitanista en sus etapas iniciales, así como las intrincadas relaciones que tuvo con el Partido Liberal y con el resto de las organizaciones políticas de izquierda del momento.

Palabras clave: movimientos sociales; opinión pública; prensa; sociología histórica; Colombia.

\section{Abstract}

The main objective of this article is to analyze the contents and transformations of the gaitanist newspapers Unirismo y Pluma Libre. To achieve this goal, the methodology developed is based on an approach to the discursive strategies through which the members of the gaitanist movement shaped a set of opinions and political actions. The interpretation that is made, begins at the conceptualization of such media as cognitive entrepreneurs. As a general conclusion of the analysis proposed, the organizational and ideological difficulties experienced by the Gaitanist movement in its initial stages are recognized, as well the intricate relationships it had with the Liberal Party and with the rest of the left wing organizations of the period..

Keywords: Social Movements; Public Opinion; Historical Sociology; Newspapers; Colombia.

¿Cómo citar este artículo? / How to quote this article?

Charry-Joya, C.A. (2019). Unirismo y Pluma Libre. Expresiones y transformaciones de la prensa gaitanista de los años 30. Sociedad y economía, (38), 64-88. https://doi.org/10.25100/sye.voi38.7134 


\section{Introducción}

Los estudios que de una u otra forma han abordado la formación de la prensa obrera en las primeras décadas del siglo XX en Colombia (Pecaut, 1973; Archila, 1985; 1986; 1991; Núñez, 2006a; 2006b), han dejado abierta la pregunta sobre la repercusión ejercida en ella por el gobierno de Revolución en marcha del liberal Alfonso López Pumarejo (1934-1938). Ya que, como es conocido, una de las principales estrategias de dicho gobierno fue la de configurar una compleja coalición con las organizaciones políticas de izquierda, entre las que se cuentan los sindicatos, los comunistas, así como los socialistas que habían migrado hacia las facciones de izquierda del Partido Liberal (Tirado, 1981). En medio de ese contexto, surgió la Unión Nacional de Izquierdas Revolucionarias (UNIR), organización política fundada por diversos intelectuales que contó con el liderazgo de Jorge Eliécer Gaitán y con el apoyo editorial de diferentes medios de comunicación escrita, entre los que se destacan los periódicos Unirismo y Pluma Libre.

No obstante, algo sobre lo que pocas veces se reflexiona es sobre las implicaciones que tiene la creación y sostenimiento de un medio de comunicación. Como lo han señalado diversos estudios (Van Dijk, 1990; Price, 1995; Monzón, 1996; Chicharro y Rueda, 2005; McCombs, 2006; Thompson, 2006; 2007), la creación y funcionamiento de un medio de comunicación es un hecho de una compleja envergadura social y política, que implica un proceso que va más allá del deseo y de las aspiraciones individuales de una persona. Es por esto que dicho proceso debe ser considerado como una empresa de carácter colectivo, en el que se articulan diversos actores sociales, dando cuenta de un conjunto de habilidades, tanto organizativas (en lo relativo a la coordinación y consecución de recursos de orden material, así como de determinados conocimientos técnicos), como de orden intelectual, que son los que hacen que ese medio se constituya en un espacio de divulgación de un conjunto de ideas más o menos comunes, sobre una serie de temas y problemáticas específicas (Borrat, 1989).

Dadas las particularidades que tuvo el movimiento gaitanista, el cual para algunos expertos debe ser caracterizado como una forma atípica e informal del populismo latinoamericano (Pecaut, 2000; 2002), lo que resulta determinante es considerar la relación que, en general, han ejercido los medios de comunicación en la creación y consolidación de los movimientos sociales; pues es a partir de la creación y/o interacción con los medios, como los activistas y líderes de los movimientos sociales han construido a lo largo de la historia redes de acción y de asociación, con las cuales han buscado superar las contingencias sociales, culturales y geográficas, haciendo posible la coordinación de esfuerzos encaminados hacia la consecución de un conjunto de objetivos políticos (Gamson y Wolfsfeld, 1993; Tarrow, 2004; Neveu, 2006).

$\mathrm{Al}$ ser entendidos de esta manera, los medios de comunicación que se definieron o autoproclamaron como gaitanistas pueden ser concebidos como una forma de acción colectiva, es decir, como una acción concertada y coordinada hacia la consecución de uno o varios objetivos políticos (Kriesi, 1999; Neveu, 2006). O bien, como un intento de constituir lo que Gramsci denominó como intelectual colectivo (Pecourt, 2008). Pero más allá de ello, este texto parte de la tesis según la cual Unirismo y Pluma Libre fueron publicaciones que dieron cuenta de la manera como sus editorialistas pretendieron constituirse como empresarios cognitivos; noción que está estrechamente relacionada con lo que es o representa el proceso de formación de la opinión pública.

Dicho proceso es entendido aquí como un tipo de campo social específico, el campo social demoscópico, el cual se define como:

\footnotetext{
el espacio social distintivo en el cual se forma, circula y manifiesta la opinión pública. Eso hace pensar en la public opinion como el resultado de un conjunto de flujos comunicativos, cognitivos y simbólicos (racionales y emotivos, individuales y colectivos, interiores y exteriores). De esta manera, nunca es el producto unilateral de un solo componente (la opinión pública como la opinión de las elites o como opinión de masas) sino el resultado de un proceso de reconstrucción e influencia múltiple: su génesis pluralista (Grossi, 2007, p. 123).
} 
De este modo, lo que nos interesa rescatar de la teoría del campo demoscópico es el papel que cumple el empresario cognitivo, pues este es el encargado de insertar "determinados núcleos cognitivos y simbólicos que luego se vuelven objetos de enfrentamiento y negociación y que conllevan a su vez a la formación de la misma opinión pública" (Grossi, 2007, p. 143). De esta manera, para fines prácticos, en esta investigación por empresario cognitivo se entiende:

como aquel tipo de actor social (individuo, grupo, organización) que asume la tarea (y el riesgo) de promover, activar y orientar, un determinado proceso de opinión de relevancia social y colectiva, tanto como portador de intereses -el empresario cognitivo invierte en bienes inmateriales- como de competencias; sabe cómo presentar las cuestiones, sabe cómo comunicar las problemáticas, es capaz de expresar orientaciones bien argumentadas y está dotado de un capital de opinión valorizable dentro la esfera pública (Grossi, 2007, p. 144).

Es por esto que el objetivo central de este artículo es el de analizar cómo los representantes del movimiento gaitanista en los años $30^{2}$ pretendieron constituirse en empresarios cognitivos, intención que quedó parcialmente plasmada en los periódicos Unirismo y Pluma Libre, los cuales no solo deben ser entendidos como medios de difusión ideológica o propagandística, sino que representaron, cada uno, una manera específica de querer formar y proyectar un tipo particular de público ${ }^{3}$. De este modo, conviene señalar que este estudio no

2 Se entiende acá que el movimiento gaitanista se constituyó como una forma de acción colectiva configurada en torno a la ideología gaitanista; por esto, partimos del hecho de que al autodenominarse como "gaitanistas", los medios de comunicación que se abordarán se subscribieron y autoidentificaron como parte de dicho movimiento sociopolítico.

3 Para Gabriel Tarde (1986), la principal diferencia entre el público y la multitud consiste en que la fuerte cohesión social del primero se debía a un hecho crucial y ausente en la segunda: la pretensión de formar una opinión, lo que en palabras de Tarde significaba la creación, en un grupo amplio y diverso de individuos, de una serie de valores y creencias más o menos comunes acerca de uno o varios temas, a partir de un trabajo mediado $-\mathrm{y}$, por consiguiente, a distancia- que podría extenderse por un prolongado periodo de tiempo. pretende hacer un análisis del proceso de recepción, el cual requeriría del abordaje y desarrollo de otro tipo de fuentes y metodologías; ni tampoco se trata de hacer una historia o trayectoria intelectual de los editores o encargados de estos medios, pues se parte del principio de tomar a estos periódicos como productos mediáticos (Thompson, 2007), que, como todo producto, fueron fabricados con un fin.

Para el desarrollo de este objetivo, el texto se estructura a partir de dos secciones -cada una de ellas dedicadas a cada medio de comunicaciónasí como de unas conclusiones. No obstante, se llama la atención sobre la extensión y el alcance de cada una de estas secciones, pues la construcción de ellas dependió de la riqueza y profundidad dada por las propias fuentes, desbalance que obedece también a los diferentes procesos sociales que permitieron la aparición y difusión de cada uno de estos medios, cuya característica común fue la de autodenominarse como gaitanistas.

Los medios de comunicación seleccionados se analizarán a partir de la relación entre texto y contexto, propia del análisis del discurso (Van Dijk, 1997). A la que se añade la interpretación propuesta por el análisis sociológico del discurso (Ruiz, 2009), en donde este es entiendo por su condición múltiple de ser información, ideología y producto social al mismo tiempo. De allí que el discurso sea analizado como un constructor de significado y fabricador o transformador de realidades sociales y políticas.

Si bien se tomaron todas las ediciones de los periódicos señalados, se enfatizó en aquellos números o contenidos (editoriales, columnas, secciones, etc.) en los cuales los editorialistas hicieron referencia a los contornos ideológicos, organizativos o estratégicos del movimiento. Esto permite comprender lo que tales actores concebían como movimiento gaitanista, así como su función y lugar en el panorama político colombiano del momento. Por su parte, dadas las profundas diferencias en cuanto a formato, diseño y distribución, el análisis que se propone parte de la consideración de cada medio como 
un caso particular que, por extrapolación, será comparado para comprender esa realidad densa que fue la configuración del naciente movimiento gaitanista en la década de 1930.

\section{Unirismo: el primer intento de crear un medio de comunicación gaitanista}

Unirismo fue un medio de comunicación fundado por Jorge Eliécer Gaitán junto con un grupo de políticos e intelectuales disidentes del Partido Liberal y del Partido Socialista, a un año de haberse creado la Unión Nacional de Izquierdas Revolucionarias (UNIR) 4 . Unirismo era un semanario que salía todos los jueves y tuvo una vigencia continua de 13 meses, entre junio de 1934 y julio de 1935. A pesar de ser un semanario, se trató en un principio de un periódico robusto, de tipo tabloide, a 16 páginas (cuando las dimensiones normales de un diario eran de 8), a dos colores, con secciones informativas diferenciadas entre noticias de última hora, editorial, notas, salud, educación, una sección de información telegráfica y otra dedicada a noticias internacionales denominada como Panorama Universal. Su tiraje se encontraba entre los 4000 y 5000 ejemplares, que eran distribuidos mayoritariamente en los departamentos de Cundinamarca, Tolima, Boyacá y Santander, siendo su epicentro la ciudad de Bogotá. Su método de distribución fue la venta, con un costo de 5 centavos.

Contó con una columna dedicada a tratar los temas de la clase obrera, denominada Problemas obreros, y otra dedicada a tocar los temas de los trabajadores agrícolas, llamada El problema de la tierra. El orden y la continuidad de estas secciones podría variar, pero a lo largo

4 Según el testimonio de Fermín López Giraldo (1937), un ex-militante de la UNIR, crítico de Gaitán, la dirigencia de esa organización estaba compuesta por Carlos Arango Vélez, Samuel Jaramillo, José Barbosa, Luis Alberto Galvis, Absalón Achury, Miguel Galvis, Guillermo Peláez, Alberto Barbosa, Octavio Rodríguez, Julio Mendoza y Carlos Quiroga, figuras en su mayoría disidentes del Partido Liberal o del Partido Socialista. de sus 50 ediciones se mantuvo una estructura básica de información general (noticias) y de información relacionada con los fines que perseguía el movimiento, siendo usual encontrar una sección denominada Adhesiones, la cual reproducía algunos de los telegramas que llegaban a la sede del medio, reportando la vinculación de personas y/o organizaciones a la causa de la UNIR, tratándose principalmente de simpatizantes de los departamentos de Cundinamarca, Tolima y Boyacá.

Según se indicó en la edición del 22 de noviembre de 1934, el equipo editorial de este medio de comunicación estaba compuesto por Jorge Eliécer Gaitán como director, Humberto Soto como jefe de redacción, Octavio Ramírez como gerente, y Vicente Saavedra que figuraba como administrador. Este medio de comunicación tuvo como sede principal una oficina ubicada en el tercer piso del emblemático Edificio Liévano en el centro de Bogotá, contando además con una dirección de correo postal y línea telefónica.

Su principal medio de financiación fue la venta, pero contó con el apoyo comercial de importantes firmas, tales como Bayer -que publicitaba su popular Aspirina-, la Compañía Colombiana de Tabaco, la cervecería Bavaria, la Lotería de Manizales, de distinguidas sastrerías y comercios locales como la London Style, así como de la promoción de diferentes tipos de servicios profesionales, como médicos y abogados, incluso de populares tarotistas locales, quienes también llegaron a pautar en este medio.

El primer número de este periódico se caracterizó por la portada, la cual expresa con claridad la posición que jugó el movimiento gaitanista -en su etapa inicial o uniristadentro del ambiente político que se estaba fraguando al calor de las reformas anunciadas por el gobierno de Revolución en Marcha, que estaba próximo a posesionarse.

En una inmensa caricatura titulada "El rey ha muerto, viva el rey" (Figura 1), los editorialistas 
de Unirismo trataron de reproducir lo que para ellos significaba el inicio del gobierno de López Pumarejo, al exponer la figura del electo presidente, quien caminaba hacia un abismo llevando de la mano a un esqueleto en cuyo cráneo se podía divisar la frase "Constitución del 86"; con lo cual se hacía referencia a las cualidades generales que para este grupo de editorialistas poseía la Carta Política colombiana de aquel entonces.

Figura 1. Primera plana del primer número de Unirismo

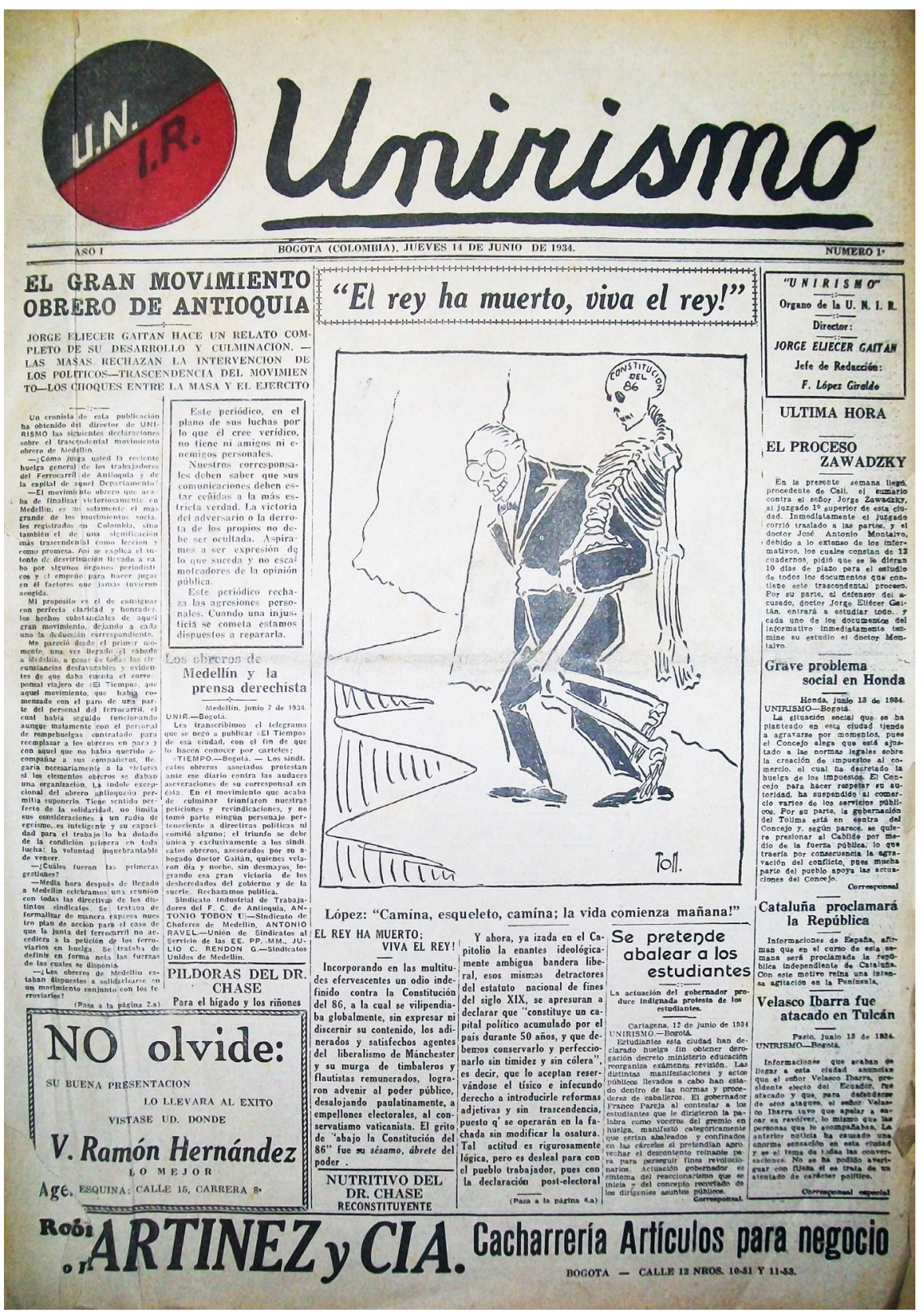

Fuente: Unirismo, 14 de junio de 1934. 
Al pie de esta caricatura, los editorialistas de Unirismo expusieron su posición y crítica al respecto, sobre lo cual comentaban:

\begin{abstract}
Incorporando en las multitudes efervescentes un odio indefinido contra la Constitución del 86, a la cual se vilipendia globalmente, sin expresar ni definir su contenido, los adinerados y satisfechos agentes del liberalismo de Manchester y su murga de timbaleros y flautistas remunerados, lograron advenir al poder público, desalojando paulatinamente, a empellones electorales, al conservatismo vaticanista. El grito de abajo la Constitución del 86 fue su sésamo ábrete (sic) del poder. Y ahora, ya izada en el Capitolio la enantes ideológicamente ambigua bandera liberal, esos mismos detractores del estatuto nacional de fines del siglo XIX, se apresuran a declarar que constituye un capital político acumulado durante 50 años $y$ que debemos conservarlo y perfeccionarlo sin timidez y sin cólera (Unirismo, 14 de junio de 1934, p. 1).
\end{abstract}

Expresión que da cuenta de la oposición que haría la UNIR a la idea expresada por el oficialismo liberal de "mejorar" y no de reformar por completo la que ya para ese momento era considera como "autoritaria" y "obsoleta" constitución política colombiana, por lo cual se infiere que uno de los principales objetivos del movimiento gaitanista de ese entonces era lograr una transformación radical de las estructuras jurídicas del Estado.

A un lado de esta caricatura apareció la noticia del día, la cual tipificaría otra de las líneas editoriales de esta publicación. La noticia se titulaba "El gran movimiento obrero de Antioquia" y su encabezado contenía los siguientes avances informativos: "Jorge Eliécer Gaitán hace un relato completo de su desarrollo y culminación. Las masas rechazan la intervención de los políticos. Trascendencia del movimiento. Los choques entre la masa y el ejército".

Esta noticia hacía alusión a las recientes manifestaciones y protestas que habían ocurrido en Medellín a raíz del levantamiento organizado por los obreros del Ferrocarril de Antioquia, he- chos en los cuales estuvieron inmiscuidos los líderes del movimiento socialista revolucionario Ignacio Torres Giraldo y María Cano, y al que fue invitado Gaitán por decisión expresa de los obreros, con el fin de coordinar y asesorar las acciones legales que estos deberían emprender en su lucha contra los patronos. El hecho que se informara de tales acontecimientos hizo que Unirismo se circunscribiera como un medio de comunicación que pretendía defender los derechos de los obreros, llegando incluso en un momento a autodenominarse como "la antorcha del proletariado colombiano" (Unirismo, 19 de julio de 1934, p. 13).

Resulta igualmente peculiar encontrar que este medio de comunicación no contara con un subtítulo o emblema característico, tal y como lo acostumbraba la prensa obrera de aquel entonces, en donde se solía declarar la afiliación específica a un gremio o a un sindicato en particular. No obstante, las secciones, columnas y contenidos que caracterizaron los primeros números de este periódico confirman que los editorialistas de este medio hicieron un gran esfuerzo y expresaron una abierta inclinación por informar y tratar temas relacionados con los obreros o con lo que en la época se denominaba coloquialmente como la clase obrera, en la que también se incluía a los trabajadores agrarios o colonos, llegando incluso a publicar una sección de Arte y Literatura en donde existía una columna denominada como Poesía revolucionaria.

A tal punto era el grado de interés expuesto por esta clase de temas, que de forma reiterada se informaba de los avatares y triunfos del movimiento obrero internacional, a través de la publicación de noticas sobre huelgas y paros obreros en Estados Unidos y Europa. A su vez, era de especial interés la evolución que tenía el movimiento republicano español, visto como un ejemplo de lucha de izquierdas que debía ser seguido por los obreros y, en general, por los revolucionarios colombianos. Razón por la cual no era extraño encontrar espacios en los que se publicaban entrevistas con los líderes de la izquierda española del momento, tales como Francisco Largo Caballero (22 de noviembre de 
1934) y Marcelino Domingo (24 de enero de 1935). Mientras tanto, en la página central de la edición del 16 de agosto de 1934, se destacaba como todo un éxito el hecho de que el Partido Socialista Argentino invitara por Colombia a la UNIR al Congreso Socialista Iberoamericano, el cual se realizaría en el mes de septiembre de ese año.

Asimismo, Unirismo pretendió constituirse como un medio de comunicación que mantenía a su público informado sobre el estallido y el desarrollo de las huelgas y manifestaciones obreras en los distintos puntos de la geografía nacional, a su vez que denunciaba con vehemencia los desalojos de los que eran objeto los trabajadores agrarios por parte de los inescrupulosos terratenientes que solían corromper a los alcaldes municipales para que ordenaran la entrada en acción de las fuerzas armadas.

Es de destacar que los comentarios editoriales que aparecieron en los primeros números de esta publicación, daban cuenta de una abierta intensión de formación ideológica, abordando temas como la relación o diferencia entre religión e ideología, entre sindicalismo y anarquismo, entre individualismo y colectivismo, y demás temas afines. Y si bien a lo largo de su historia Unirismo trató de ser un medio de comunicación dirigido a la clase trabajadora, también pretendió crear puentes con otros sectores sociales, en especial, con los jóvenes universitarios.

En la sección Educación (Figura 2) solían aparecer artículos escritos por estudiantes de Dere- cho, Medicina o Filosofía, que hablaban sobre las pésimas condiciones y el estado de atraso intelectual y científico que vivía la universidad colombiana, al tiempo que abría espacios para que algunos jóvenes líderes políticos escribieran allí sus arengas y apreciaciones.

Y si bien hemos señalado que los editorialistas de Unirismo pretendieron crear puentes ideológicos con diferentes sectores sociales, entre los que se cuentan los obreros industriales, los trabajadores agrícolas y los universitarios, debemos señalar también que, en comparación con lo expuesto en relación a otros grupo sociales, fueron pocos los espacios que los editorialistas de este medio dedicaron a las mujeres, a pesar de que fuera el propio Jorge Eliécer Gaitán quien para la época insistiera en un proyecto de ley que pretendía reconocer los derechos civiles de la mujer.

Por lo general, la participación de la mujer estaba restringida a las notas de salud o de arte y literatura, en las que se expresaba la intensión de informar al público femenino, a tal punto que solo se pudo constatar la existencia de una única sección (del 26 de julio de 1934) titulada Feminismo y feminidad, en donde se abordó el tema de cuál debería ser el rol de la mujer en el comercio y en el desarrollo económico de la nación.

Aun así, podemos afirmar que, contrario a lo que representó para la prensa obrera y socialista de la época (Archila, 1985; 1986), para los editoria-

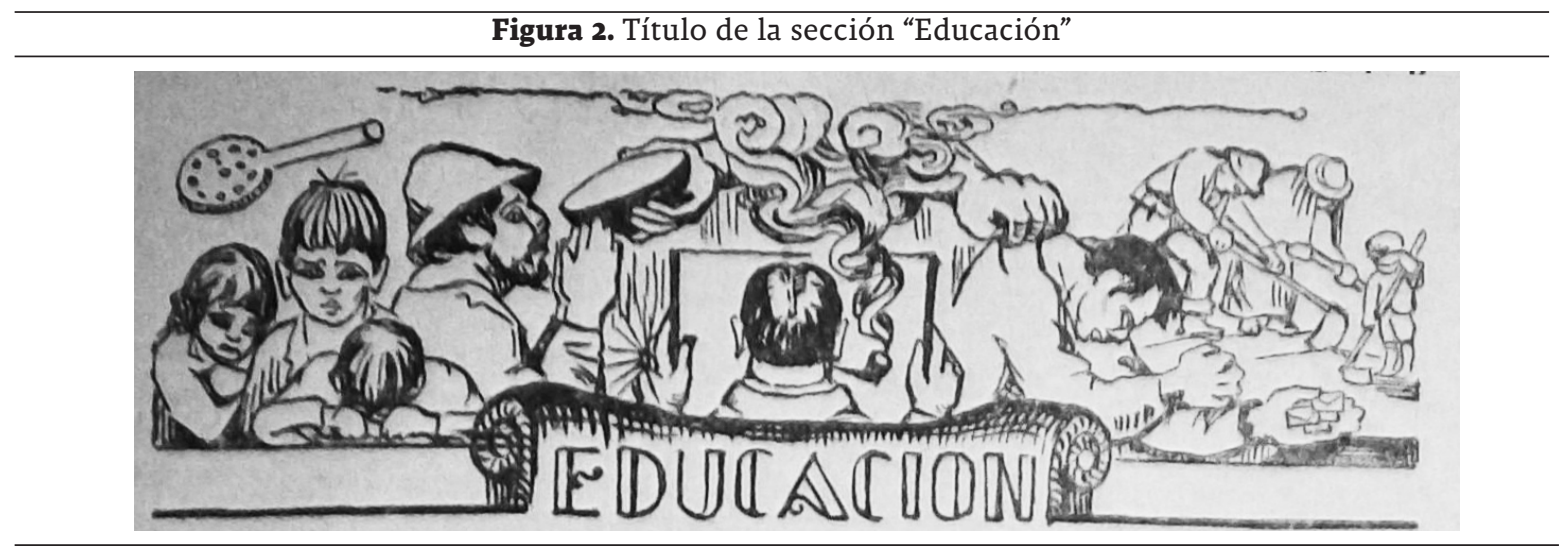

Fuente: Unirismo, varias ediciones de 1934. 
listas de Unirismo la mujer debía ejercer un rol protagónico y determinante en la transformación de la sociedad, idea que fue expuesta en la columna de Poesía revolucionaria del 30 de agosto de 1934, en donde se dedican unas palabras alegóricas a la mujer proletaria. Algunos apartes de dicha poesía exclamaban lo siguiente:

\footnotetext{
En tu sueño se alojan los inviernos, mujer proletaria, y tus dolencias áridas cobijan las orquestas de los vientos errantes [...] Mi vos colectiva te alaba, grande como hipérbole sostienes la firmeza de las emociones proletarias, y el color de las banderas [...] Mujer proletaria, por ti los fusiles obreros dirán su canción el $1^{\circ}$ de mayo/ Deja que mis versos apoyen la frente en tu falda, como todas las tardes el cielo, mientras tus penas por los ríos maduros de la revolución, descienden como piraguas (Unirismo, 30 de agosto de 1934, p. 13).
}

Otros de los grupos sociales, sobre los cuales expusieron algún interés los editorialistas de Unirismo, fueron los indígenas y los afrodescendientes. Con comentarios editoriales como " $\mathrm{La}$ belleza entre los negros y sentido social de razas" del 30 de agosto de 1934 -en el cual se hizo un extenso reportaje del África subsahariana, destacando la belleza natural de las personas que habitan ese continente-, se buscaba resaltar las cualidades y valores de la gente negra, así como de las huellas que la trata había dejado en América y en Colombia, las cuales habían nutrido con riqueza y diversidad la cultura y la sociedad nacional.

Aun así, lo cierto es que la mayor parte de las apreciaciones que emitió este medio de comunicación, sobre el papel que jugaba la población negra colombiana, pasaba por el crisol de la denuncia de ser un grupo humano explotado y marginalizado (es decir, en clave de clase), en particular por los enclaves económicos extranjeros como la británica Chocó-Pacífico Co. Esta empresa se había instalado en inmediaciones de los municipios chocoanos de Andagolla y Condoto, de donde extrajo grandes cantidades de oro usando a la población negra local como mano de obra barata. Llegó incluso a configurar una ex- traña y compleja forma de organización social, que por lo enunciado en este medio, era similar a lo que sería el apartheid sudafricano (del cual no han existido otras expresiones semejantes en Colombia). Unirismo dedicó algunos reportajes a denunciar esta situación, siendo a su vez usual encontrar un número importante de telegramas que anunciaban la adhesión de los mineros de esta región colombiana a la causa de la UNIR5.

Por su parte, la creación de puentes ideológicos con la población indígena pasaba por la comparación con otras experiencias nacionales. Por ejemplo, en la columna "El indio como factor social" del 13 de diciembre de 1934, los editorialistas de Unirismo trataban de demostrar la importancia cultural y política que habían adquirido los pueblos indígenas norteamericanos, que ya contaban con una reunión o congreso nacional anual, en el cual se discutían los asuntos más críticos que vivían estas poblaciones. Así mismo solían recalcar el legado dejado por las culturas indígenas en la construcción de la identidad nacional mexicana y peruana. Posteriormente, en la columna "Las conquistas del indio para la civilización", se llegó a cuestionar el sistema de educación nacional, que pretendía obligar a los hijos de los indígenas a asistir diariamente a la escuela, lo cual implicaba una severa transformación de las formas de reproducción de la economía familiar, en donde el infante indígena solía cumplir funciones claves (Unirismo, 24 de enero de 1935, p. 8) ${ }^{6}$.

Sin embargo, -y más allá de la diversidad de públicos con los cuales pretendió establecer

5 Un tema que en realidad ha sido poco investigado y tenido en cuenta por las Ciencias Sociales colombianas, las cuales han puesto un mayor interés en estudiar los enclaves económicos tradicionales ubicados en la zona bananera y en la zona de extracción petrolera apostada sobre el río Magdalena. Respecto a la situación de los obreros de la Chocó-Pacífico consúltense las ediciones de Unirismo del 18 de octubre de 1934 (p. 1); del 15 de noviembre de 1934 (p. 8); del 22 de diciembre de 1934 (p. 6); del 29 de noviembre de 1934 (p. 6); del 6 de diciembre de 1934 (p. 3) y del 20 de diciembre de 1934 (p. 6).

$6 \mathrm{Al}$ respecto, consúltese también los comentarios editoriales del 31 de enero de 1935 (p. 8) y del 28 de marzo de 1935 (p. 4). 
relaciones o afinidades de orden ideológicoUnirismo fue, fundamentalmente, el medio de comunicación de una organización política: la UNIR, cuyo escudo aparecía a un lado del título del periódico en rojo y negro, colores cercanos a la simbología comunista de la época, sin que ello llegase a implicar que los editorialistas de este medio se identificaran con el comunismo o con el Partido Comunista.

De hecho, en la columna "Sentido común y comunismo", los editorialistas de Unirismo atacaron duramente a esta ideología y a sus representantes, sobre lo cual comentaban:

\begin{abstract}
Un examen de las tácticas del partido muestra una combinación de débil teoría y conmovedora comedia. Sus enemigos internos son legión y están constantemente expulsando gran número de sus miembros". A lo cual agregarían: "El comunismo crece en el cuerpo social como una infección en el cuerpo humano. En ambos casos hay un germen, y conviene atacarlo directamente (Unirismo, 14 de febrero de 1935, p. 8).
\end{abstract}

En la edición del 19 de julio de 1934 se llegó a definir al movimiento unirista como un partido político, que pretendía ofrecer a la ciudadanía colombiana una alternativa política distinta al tradicional bipartidismo; caracterizado por los editorialistas como organizaciones "burócratas" y "demagógicas", cuyo único capital político era producto del clientelismo o del despotismo. Contrario a lo cual se postulaban las siguientes palabras como los pilares fundamentales del movimiento:

... el partido Unirista de Colombia, el que hoy marcha a la vanguardia del progreso y la civilización, ha empezado con gran entusiasmo a formar sus huestes rebeldes para demostrar que en la inmensa mayoría de sus soldados valerosos que lo integran, bullen los anhelos reformativos y el ardiente deseo de terminar definitivamente con el cruel antagonismo y las perjudiciales divergencias que han ido, paso a paso, llevando al país por el camino del retroceso y del fracaso (Unirismo, 19 de julio de 1934, p.10).
Declaraciones que ubicaban al movimiento unirista no sólo en la pugna por lograr una transformación profunda del sistema jurídico colombiano, sino también dentro de un abierto e incuestionable marco de lucha de clases. Por último, Efraín Rojas señalaba que la tarea que tenía por delante el nuevo partido no era, por cierto, nada cómoda, sin embargo, enfatizaba que tales esfuerzos y sacrificios terminarían con la emancipación del trabajador colombiano de los condicionamientos que imponía el individualismo capitalista, objetivo que se lograría a partir de una apertura real de los campos de la democracia, lucha que sería reconocida y valorada por las generaciones actuales y por las venideras (Unirismo, 19 de julio de 1934, p. 10).

Por tratarse de un medio de comunicación que respondía a los intereses de una organización política, no era extraño encontrar en las páginas de Unirismo una abierta pretensión de crear una simbología en torno al movimiento. Ejemplo de ello fue la edición del 6 de septiembre de 1934, en donde apareció en primera plana una ilustración que ocupó la mayor parte de la página en la que se exponía la bandera unirista (Figura 3), considerada como uno de los emblemas

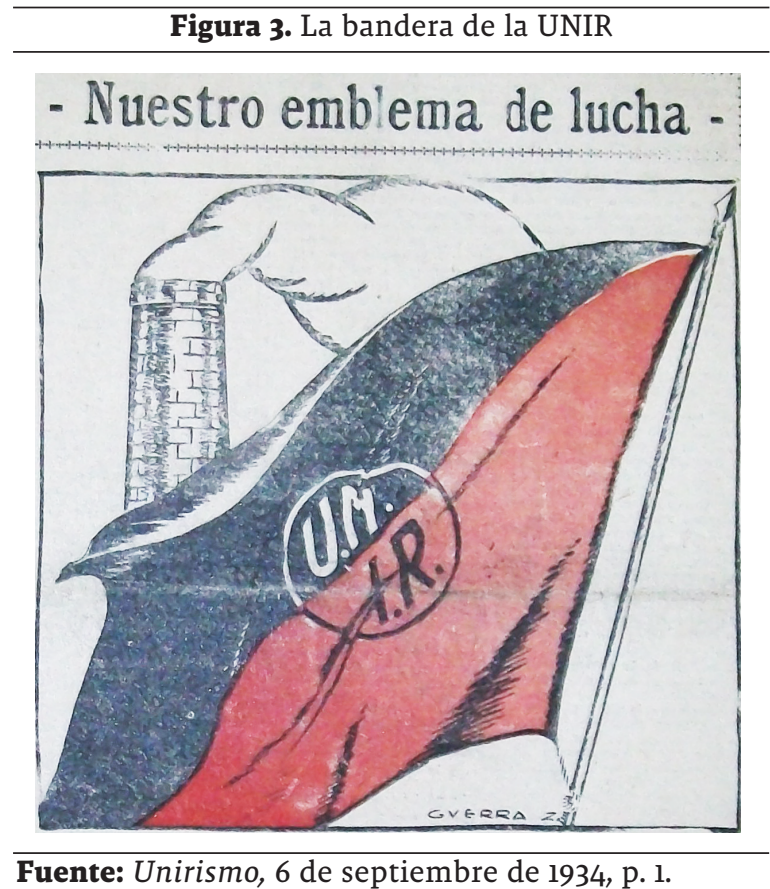


más importantes de la organización, en el que se destacan de nuevo los colores rojo y negro y el escudo de la UNIR en el centro, mientras que en el fondo se percibe una chimenea industrial. Posteriormente, en la edición del 22 de noviembre de 1934, en una de las páginas interiores del periódico se publicó el "Canto unirista", composición hecha por el militante Miguel Agudelo y reproducida en la popular sección Poesía revolucionaria, cuyo contenido devela con claridad la orientación dada en un principio al movimiento de ser un adalid de las causas de los trabajadores industriales y campesinos de Colombia, canción que por lo demás finaliza con la frase que caracterizó a la organización: "iMuerte al pasado. Revolución hacia el porvenir!”.

Por su parte, denotando su extranción obrera, algunas estrofas del canto unirista indicaban lo siguiente:

Hermano obrero, que trabaja de sol a sol, para recibir sólo las migajas en el banquete del señor. Hermano que doblas la cerviz altiva sobre el surco primaveral para que el latifundista en un eterno carnaval. Es tiempo ya de alzar la frente y empuñar el rojo pendón, hermano de mirada ardiente y garras de león (Unirismo, 11 de noviembre de 1934, p. 8).

Aun así, el principal símbolo del movimiento unirista, lo que hizo de este un movimiento gaitanista, fue precisamente el hecho de divulgar y promover políticamente las ideas y la figura que para ese momento ya era considerada como la cabeza más visible del movimiento: Jorge Eliécer Gaitán. Fueron constantes las alusiones hechas por los editorialistas de Unirismo a Gaitán, reproduciendo comentarios favorables sobre sus intervenciones en el Congreso de la República, o pidiendo su opinión sobre determinados temas de orden político o jurídico. Noticias que solían aparecer en primera plana, acompañadas de una foto o de una caricatura del líder del movimiento (Figura 4).

De hecho, el caso más característico de esta tendencia fue la amplia cobertura dada por el periódico a la entrevista que uno de sus repor-

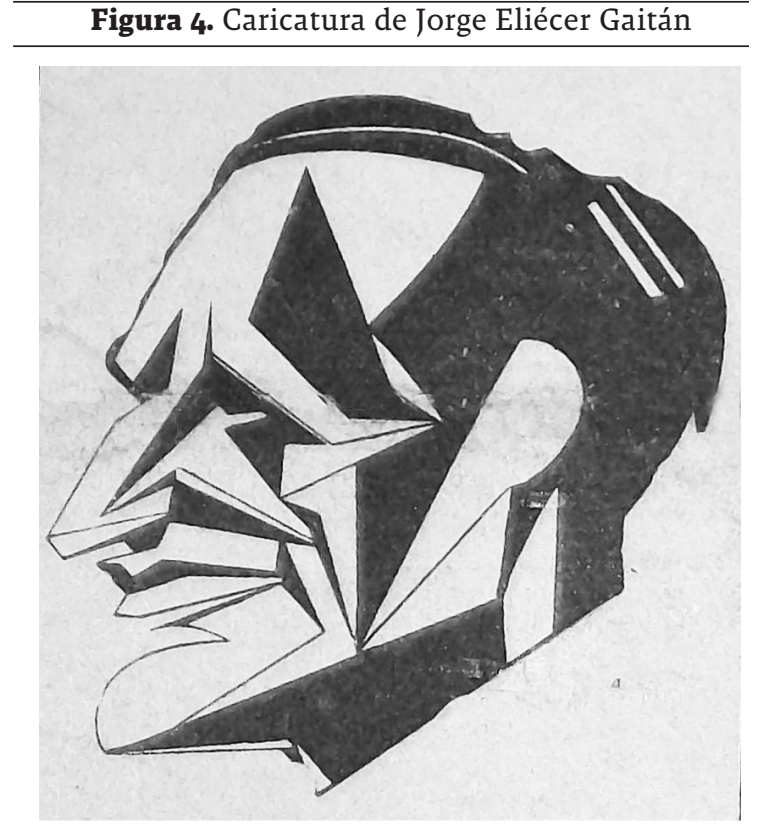

Fuente: Unirismo, 23 de agosto de 1934.

teros hizo a Gaitán, de donde se extrajeron los principios estatutarios del movimiento. Esta entrevista fue titulada por los editorialistas del periódico como la "Plataforma de Acción" siendo denominada posteriormente como el Manifiesto del Unirismo, texto que fue reproducido en su totalidad en la página central e interiores de la edición del 23 de agosto de 1934.

No obstante, lo que se puede apreciar es que para diciembre de 1934 el semanario sufrió un importante recorte, producto del reducido presupuesto que los editorialistas disponían para su producción, pasando de una edición de 16 páginas a una de 8 páginas. De tal recorte, la única sección que se mantuvo vigente, aparte de las noticias generales y la nota editorial, fue la de Problemas obreros (Figura 5), mientras que la antigua sección El problema de la tierra fue perdiendo continuidad, apareciendo en muy contadas ocasiones.

A partir de este momento, se percibe un tono más partidista en lo que tenía que ver con las constantes denuncias de los abusos y escándalos de corrupción administrativa que estaban 


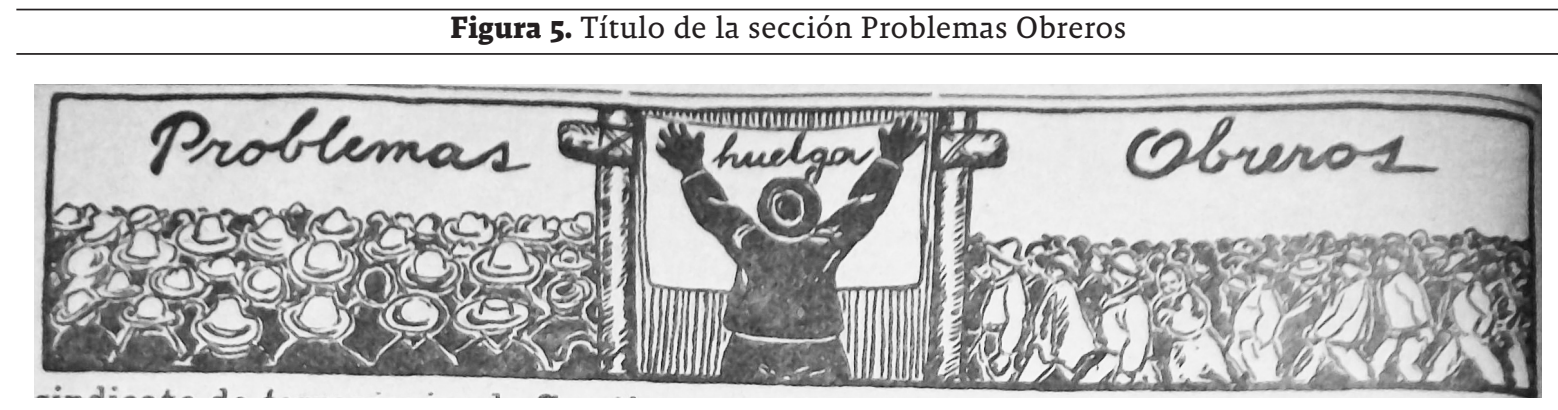

Fuente: Unirismo, varias ediciones de 1934.

ocurriendo en el país; siendo claro a su vez que las noticias y demás espacios editoriales del medio se insertan en una abierta crítica al restringido bipartidismo en el cual se soportaba la democracia colombiana. Estas críticas eran intercaladas con grandes titulares en los que se denunciaba a su vez la corrupción existente en la Iglesia Católica, a partir de la enunciación de severos escándalos sobre evasión de impuestos, peculados y abuso de autoridad, siendo de especial atención la denuncia de la intención de la Iglesia Católica de implantar la censura7.

Por los motivos anteriormente señalados, es posible constar un cambio en la línea editorial del periódico hacia finales de 1934, puesto que para los primeros números era usual encontrar un nutrido número de reportajes y notas sobre las difíciles condiciones que atravesaban los colonos de haciendas como El Limón, Tolima y El Chocho (entre muchas otras); o de amplias regiones agrícolas como la zona bananera de Ciénaga o los centros de producción cafetera del centro andino del país. Esta información era complementada con una sección de Agricultura (Figura 6), en donde se publicaban notas relacionadas con las mejores técnicas de cultivo, el uso eficiente de productos agrícolas y, en general, sobre cómo se podría hacer un uso racional (industrial) de la producción agrícola.

Y si bien se puede afirmar que tales espacios editoriales no desaparecieron por completo,

$7 \mathrm{Al}$ respecto, consúltese también la edición de Unirismo del 28 de febrero de 1935, en donde se reproduce la entrevista hecha por El Espectador a Gaitán. En relación al tema de la censura, consúltese la nota "Ecos de una censura", publicada en la edición del 21 de febrero de 1935. lo cierto es que fueron desplazados progresivamente, con lo cual se pretendió reforzar la inclinación obrerista que mantuvo este medio de comunicación desde sus inicios. Situación que bien puede dar cuenta de un cierto grado de preponderancia de la imagen del obrero industrial como modelo del obrero y del pueblo colombiano, tal y como venía ocurriendo desde finales de los años 20 en la prensa obrera analizada por Luz Ángela Núñez (2006a; 2006b). Transición que pudo haber sido favorecida por el hecho de que el obrero industrial tenía un acceso más directo a la lectura y a la prensa, por tratarse de un grupo social vinculado con las dinámicas y las formas de reproducción de la vida urbana.

En el caso del periódico Unirismo, estas transformaciones en la línea editorial dieron como resultado la creación de una nueva sección denominada Columna sindical, la cual comenzó a aparecer desde enero de 1935. Esto da cuenta de que, poco a poco, el movimiento unirista iba siendo subsumido por la corriente centrípeta originada en el oficialismo liberal, desde la cual ese partido pretendía hacerse con las organizaciones -y con los votantes-adscritos al movimiento obrero colombiano.

De hecho, si para diciembre de 1934 en las páginas de Unirismo se mantenía vigente el tono beligerante con el cual había empezado este medio de comunicación, para febrero de 1935 -luego de que López Pumarejo y sus ministros (entre ellos Darío Echandía, un amigo cercano de Gaitán) oficializaran el proyecto de reforma constitucional- los editorialistas de Unirismo empezaron a adoptar una posición más com- 


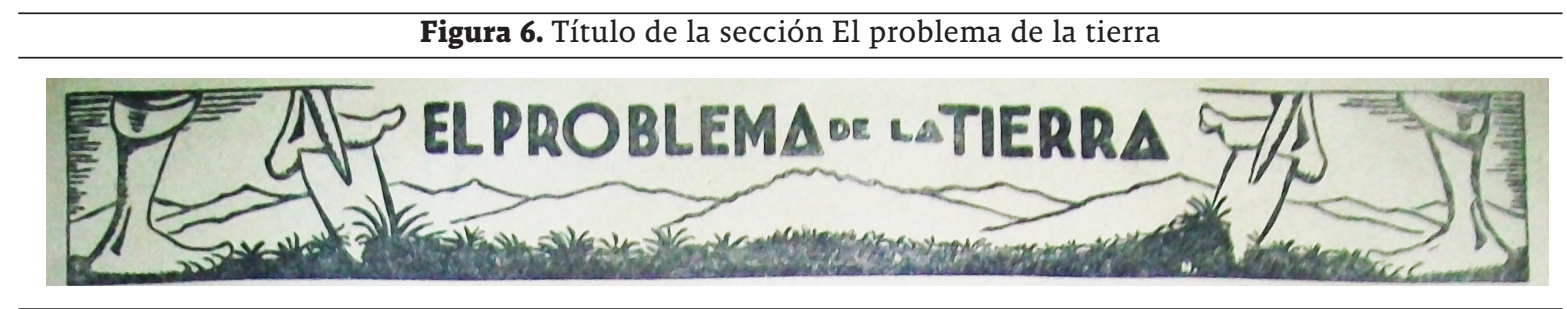

Fuente: Unirismo, varias ediciones de 1934.

prensiva y medianamente favorable frente a esa iniciativa legislativa. Fue por ello que las críticas que solía hacer este medio al Partido Liberal pasaron a concentrarse en los abusos y desmanes cometidos por los directorios regionales y municipales de dicho partido, tendencia que se vio acompañada de un recrudecimiento de las acusaciones contra el Partido Conservador.

Luego de toda una serie de reportajes favorables en torno a las acciones emprendidas por el ministro de Gobierno, Darío Echandía, en las que se destacaba el trato de camaradería y la cercanía política que existía entre este y Gaitán, se pretendió difundir la idea según la cual todos los liberales (incluida la izquierda revolucionaria) deberían estar unidos para defender las reformas del ataque de los conservadores, tal y como quedó expuesto en la primera plana de la edición del 20 de diciembre de 1934. Mientras tanto, para el 24 de enero del 35, este medio de comunicación destinó un amplio espacio editorial en el cual se hizo una férrea defensa del principal y más polémico proyecto legislativo asociado con el gobierno de López Pumarejo: el proyecto de reforma agraria, el cual era definido por los editorialistas de Unirismo como "una necesidad suprapartidista" (Unirismo, 24 de enero de 1935, p. 5). Comentario que fue acompañado de un renacer de las denuncias que solían hacer sobre los desalojos y maltratos que recibían los trabajadores agrarios de parte de los terratenientes y de las fuerzas armadas, como una forma de justificación de la gran importancia que revestía dicho proyecto de ley.

Paulatinamente, se completaba la parábola del movimiento unirista hacia la coalición política que pretendía urdir el oficialismo liberal, con la cual esa organización política deseaba posicionarse como un partido de centro-izquierda. Tal transición se profundizaría hacia los primeros días de febrero de 1935, momento que coincide con la publicación de una serie de comentarios en los que los editores de Unirismo ven con cierto grado de recelo, pero de forma favorable, la propuesta de reforma constitucional, llegando a presionar a los representantes del oficialismo liberal para que actuaran según los principios que anteriormente dicho partido decía defender. Asunto sobre el cual recalcaban: "Corresponde al pueblo vigilar y esperar. Mientras firme en la lucha y en el reclamo por la formación de esa nueva Colombia, y aguardar para ella la decisión audaz y valerosa de quienes pueden y deben darle realidad actuante" (Unirismo, 2 de febrero de 1935, p. 3).

Y, como era de esperarse, en medio de la competencia por saber qué organización sería de mayor utilidad y cuál de ellas cumpliría un rol más protagónico dentro de la coalición política que soportó al gobierno de la Revolución en marcha, los uniristas comenzaron a atacar con mayor vehemencia a los comunistas: no era extraño encontrar que en el periódico se aplaudiera la expulsión de los comunistas que militaban en algún sindicato, o que se denunciara, de forma cruda y directa, la falta de identidad nacional que expresaban los miembros de esa organización política.

Finalmente, muy a pesar de la aparente unidad y alta organización interna que investigadores como Cordel Robinson (1976) han atribuido a la UNIR, hacia mediados de abril de 1935 se constata una fuerte escisión del movimiento, producida por la determinación que debían tomar 
las directivas de dicha organización, sobre si debería o no inscribir algunos de sus miembros como aspirantes para optar a un escaño en las Asambleas Departamentales.

El 13 de abril de 1935 (sábado) apareció un número especial de Unirismo, en el cual se hizo un extraordinario despliegue informativo a la convención unirista departamental que se había congregado ese mismo día y convocó a miembros del movimiento (de Bogotá y de otras regiones vecinas). Fue por ello que en la página central del periódico, se reprodujo una inmensa foto de Gaitán rodeada por el listado de personas que participaron en la convención, información sobre la cual se posaba un titular que decía: "A las 12 se instaló la convención Unirista departamental de Bogotá", y cuyo subtítulo enunciaba que 123 delegaciones obreras, campesinas y universitarias estaban afiliadas a la UNIR, llegando incluso a decirse que el evento había sido transmitido en vivo por la emisora $\mathrm{HJ} 3 \mathrm{ABD}$, lo cual, sin duda, representaba todo un avance técnico y una innovación informativa para aquella época.

Los editorialistas de Unirismo decidieron reproducir la intervención hecha por Gaitán ese día, en donde reclamó de sus copartidarios mayor orden y estrategia política. En sus propias palabras: "Orden nos dicen y orden reclamamos nosotros todavía con mayor energía. No es posible hacer una revolución anárquica si ella quiere ser eficaz. Si alguien necesita de método, de disciplina, de actuación regularizada y ordenada para que sea eficaz, es el revolucionario" (Unirismo, 14 de abril de 1935, p. 2). Sobre lo cual agregaba el ya carismático líder político en tono de denuncia: "Otros de los hechos que me hacen pensar en el momento crítico y decisivo que la política colombiana está viviendo, es la ausencia de un programa concreto en las fuerzas de izquierda para la obra revolucionaria". Todo lo cual implicaba la necesidad imperiosa de formular un programa de acción conjunta de "las izquierdas revolucionarias", pues en ellas seguía presente la política caciquil que reinaba en los partidos tradicionales, en la que: "los electores son llevados a votar por personas que muchas veces no conocen, ni son capaces, ni son dignas"
(Unirismo, 14 de abril de 1935, p. 2).

Y sería en el contexto de esta asamblea que Gaitán llegaría a afirmar:

\footnotetext{
Vamos a ver en concreto, lejos de la retórica, si esas izquierdas son o no capaces de atender a un problema del cual nunca oigo hablar a los revolucionarios, y que es el de formar hombres capaces para la actuación. Comenzando por lo primero aun cuando parezca trivial, es decir, por su plenitud fisiológica. Las transformaciones son determinadas por un proceso real, pero no se actúan ni se cristalizan sino a través del tipo humano. ¿Creéis, seriamente, que entre nosotros pueda hacerse la obra de enriquecimiento colectivo que soñamos con nuestro actual tipo humano, con esa gran masa de campesinos y trabajadores que vosotros conocéis, tarados por todas las enfermedades, minados por la falta de higiene, abandonados por el Estado? (Unirismo, 14 de abril de 1935 , p. 2).
}

Y si bien queda claro que para Gaitán uno de los problemas del nivel de atraso de las masas colombianas era el alto grado de marginalización y abandono que estas sufrían, se reafirma que la forma más expedita para sacar a dichas masas de su estado de postración pasaba por la transformación de las formas jurídicas que daban sustento a un sistema de relaciones sociales desventajoso y excluyente. De esta manera, marcaba una gran diferencia frente a los supuestos orígenes genéticos a los que aludía la élite intelectual y política del país para referirse al estado de degeneración física y moral del pueblo colombiano.

Sobre lo cual ampliaba el propio Gaitán:

Vamos a saber si la obra izquierdista llega
y puede llegar a la liberación de la mitad
de los ciudadanos colombianos, proscritos
hoy de los derechos civiles por el hecho
de ser hijos naturales. Vamos a saber si el
núcleo familiar, sobre todo de nuestro pue-
blo, puede persistir abandonado, sin regla-
mentación como actualmente, en donde
perdura esa concepción romana del padre
de familia, dueño y señor sin limitaciones. 
Queremos saber si hay una codificación civil distinta que normalice las relaciones de tal género de acuerdo con los principios sociales en pugna con el individualismo. Queremos saber qué es de la intervención del Estado, efectiva y no retórica (...) (Unirismo, 14 de abril de 1935, p. 2).

Para finales de abril, el conflicto yla división entre las facciones más "comunistas" del movimiento y las gaitanistas -reunidas quizás de manera forzada en la UNIR- volverían a aparecer en las páginas de Unirismo. Con un extenso reportaje al líder y presidente nacional de la organización, los editorialistas de Unirismo pretendían argüir que la idea de presentar listas de candidatos para las elecciones de la Asamblea Departamental de Cundinamarca era en realidad una estrategia de desprestigio creada por las fuerzas políticas conservadoras, con el fin de crear una división y cambio de norte en el movimiento. Argumento con el cual se pretendía encubrir una división real y objetiva, puesto que en el seno de la organización persistían las voces, según las cuales, los directorios departamentales debían presentarse a las urnas, mientras que la posición de Gaitán y sus seguidores consistía en construir una plataforma política, con derroteros plenamente divulgados y discutidos ante los seguidores del movimiento y ante la opinión pública, y no ser meramente una organización electoral. Esta división interna fue corroborada por el ex Inspector General de la UNIR, Fermín López Giraldo, en su libro El apóstol desnudo, de 1937, en donde además de señalar el fuerte narcicismo político de Gaitán, se revela que -desde el principio- la UNIR tuvo unos estatutos que fueron modificados abruptamente por la llegada de Gaitán, en particular, por la publicación del denominado Manifiesto del Unirismo que apareció en las páginas del periódico.

A pesar de ello, la idea de configurar una plataforma política de acción venía siendo defendida por los editorialistas de este medio de comunicación desde febrero de 1935, a partir de una innovación en la edición del semanario, consistente en publicar frases emblemáticas debajo del títu- lo del periódico. Por ejemplo, en la edición del 7 de febrero se decía que: "El estado moderno debe ser el agente del engrandecimiento económico y moral de los ciudadanos y no reducto de bizantina política para beneficio de los políticos" (Unirismo, 7 de febrero de 1935, p. 1). Por su parte, en la del 21 de marzo de 1935 se afirmaba que: "La emancipación del proletariado sólo será posible y definitiva cuando los trabajadores adquieran de modo sincero y firme el sentido de solidaridad" (Unirismo, 21 de marzo de 1935, p. 1); mientras que en el subtítulo del periódico del 25 de abril de 1935 se proclamaba que: "Los partidos políticos que esquivan presentar las tesis económicas y sociales que sus voceros han de sostener en los cuerpos colegiados, carecen de razón de existir o asaltan la buena fe de las masas" (Unirismo, 25 de abril de 1935, p. 1). Esta frase se constituía en un mensaje dirigido no tanto a los contrincantes pertenecientes a otras organizaciones políticas, sino para los contradictores internos del movimiento.

Y en la medida en que la división interna de la UNIR se hacía más notoria y profunda, los editorialistas de Unirismo hacían todo lo posible por acercar más al movimiento con el liberalismo. Ejemplo de ello fue la reproducción del editorial emitido por el periódico liberal El Avance, de la ciudad de Ibagué, comentario que fue publicado por completo en la edición de Unirismo del 25 de abril del 35, en cuyos apartes se puede distinguir la inclinación que tenía el liberalismo de acercar a la UNIR a sus toldas:

La honda y nítida exposición de ideas hecha recientemente por Gaitán ante la Convención de la UNIR, nos ha enfrentado a una definida línea de conducta destinada sin duda a captar la simpatía de las masas populares en Colombia, por cuanto ella implica perspectivas de redención económica y social para las clases desvalidas. [...] la expresión del Jefe unirista nos ha colocado delante de una pauta ideológica de muy precisos contornos, ha venido también a demostrar que en un estricto plano de ideas no existen en verdad razones que puedan divorciar a las masas populares del liberalismo (Unirismo, 25 de abril de 1935, p. 3). 
En la edición del 4 de mayo se destacó en primera plana que el movimiento unirista finalmente lanzaría 16 listas de candidatos para la Asamblea Departamental de Cundinamarca y otra por el distrito electoral de Bogotá, así como también lo haría en el departamento de Antioquia, en donde se lanzó una sola lista. Aspiraciones de las que finalmente solo sería elegida la lista de Bogotá, en la que el nombre de Gaitán aparecía como el "Principal". Ante la derrota electoral sufrida, y ante el hecho de que los únicos candidatos uniristas que fueron elegidos eran gaitanistas, para el 23 de mayo se comienza a discutir en el periódico la posibilidad de que Gaitán se incorporara como candidato unirista dentro de las listas liberales, para que fuese designado como senador por el Departamento de Cundinamarca. Hecho que sería corroborado en la edición del 6 de junio, en la que se hablaba de la inminente formalización de esa posibilidad, pues por esos días dicho tema había sido discutido en la diputación del Departamento: cuerpo colegiado compuesto mayoritariamente por liberales, en donde el nombre de Gaitán había recibido una amplia aceptación y acogida.

Y en la medida en que se iban estrechando los vínculos entre la UNIR y el Partido Liberal, a lo largo de todo el mes de mayo y junio de 1935, los editorialistas de Unirismo hicieron una férrea defensa del proyecto de reforma constitucional de López, en particular por las garantías que daba el ministro de Gobierno, Darío Echandía, para que dicho proyecto fuese entendido como una plataforma de acuerdos entre el liberalismo y las izquierdas revolucionarias ${ }^{8}$. Paralelamente, se producen un conjunto de cambios en la línea editorial del periódico: apareció una nueva columna titulada "Orientaciones Revolucionarias", mientras que la sección de información telegráfica pasó a denominarse "Vibraciones de

8 Véase en particular la edición del 13 de junio de 1935, en la que se hace un amplio despliegue a esta noticia. El titular de ese día destacaba que: "El gobierno presentará al próximo congreso sustanciales reformas constitucionales", mientras que en el subtítulo se insistía en que: "El Dr. Darío Echandía esboza algunas de las reformas constitucionales que presentará el gobierno al próximo congreso". la República”, desapareciendo a su vez la recientemente creada "Columna Sindical".

Luego de su edición del 24 de junio de 1935, Unirismo reaparecería dos días antes de posesionarse el nuevo congreso que terminaría aprobando la reforma constitucional del gobierno de la Revolución en marcha, proyecto que sería sancionado bajo una concepción y orientación muy distinta a la que había sido presentado, tal y como lo ha señalado el trabajo de Sandra Botero (2006).

El 18 de julio de 1935, salió a la luz la última edición del periódico, hecho que puede ser entendido a su vez como la última expresión del movimiento unirista. El titular de ese día informaba con gran entusiasmo que: "Un fuerte grupo de parlamentarios propondrá una substancial reforma a la Constitución", mientras que en el comentario editorial, titulado "Revolucionarios y pseudo-revolucionarios", se cuestionaba la posición apostata de algunos elementos que se hacían llamar revolucionarios, pero que en realidad veían en la política un mecanismo para la realización de sus restringidas aspiraciones personales. Entre tanto, en una nota que apareció en primera plana, se reprodujo la defensa de Gaitán hecha por César Gonzáles, uno de los diputados uniristas que intervino por esos días en la Asamblea de Cundinamarca; intervención en la cual se afirmaba que la presencia de Gaitán en el Congreso representaba una oportunidad más para defender los principios que dieron vida a la UNIR, extinta ya como organización para ese momento.

\section{Pluma Libre: la breve experiencia de un medio de comunicación gaitanista regional}

Pero Unirismo no fue el único medio de comunicación que representó los fines e intereses de la UNIR. Hacia mediados de 1934, en el oriente del país, se fundó el semanario Alma Libre, periódico que apareció en la ciudad de Socorro (Santander) que sería abruptamente clausurado tras el arresto de su director, el señor Juan 
Ortiz, en hechos producidos a finales del mes de junio de ese mismo año. En la costa Caribe, el periódico El Socialista, de Barranquilla, cumplió el papel de ser el difusor oficial de las causas uniristas, recibiendo apoyo financiero de esa organización; mientras que, en el occidente colombiano, el periódico Pluma Libre de la ciudad de Pereira fue el encargado de difundir las ideas gaitanistas, recibiendo igualmente apoyo financiero de la UNIR.

Por la información recopilada, sabemos que estos medios de comunicación tuvieron total independencia frente a la línea editorial que reproducían las directivas nacionales del movimiento en Bogotá. Así lo deducimos por la información que publicó Unirismo, en su edición del 25 de abril de 1935, a raíz de la crisis suscitada en la convención unirista departamental de Cundinamarca:

\footnotetext{
Con orgullo partidista hemos visto que vosotros, compañeros de El Socialista y de Pluma Libre, os habéis impuesto por vuestra propia y espontánea voluntad los deberes inherentes a la profesión de periodistas al servicio de los ideales revolucionarios. [...] Hay que mantener a todo trance el ideal que nos congrega bajo el pabellón bicolor, negro y rojo, mirando impasibles y desdeñosos, a los que ya se van quedando en el camino, enredados en las zarzas de la claudicación (Unirismo, 25 de abril de 1935, p. 1).
}

Sin embargo, lo que resulta interesante de este conjunto de periódicos, es que ellos describen la transición ideológica y editorial que estaba produciendo la UNIR en la configuración de un sector nada despreciable de la izquierda colombiana del momento. Ejemplo de ello era El Socialista de Barranquilla que, como su nombre lo indicaba, había representado en un momento de su historia los fines e intereses del socialismo revolucionario de la época, para luego volverse un medio de comunicación unirista.

Por su parte, la primera edición de Pluma Libre apareció el 8 de julio de 1933, siendo producida en los talleres de la Imprenta Gutenberg de la ciudad de Pereira. En el subtítulo del periódico, se indicaba que este era el "Órgano de la Federación Obrera y Campesina", es decir, se declaraba que era un medio de comunicación aparentemente adscrito a una organización sindical. Sin embargo, en un recuadro ubicado en las páginas interiores se indicaba que dicho medio "Circula como órgano del Obrerismo Independiente de Pereira" (Pluma Libre, 15 de julio de 1933, p. 3.), lo cual hace pensar que no respondía de manera específica a una organización sindical que estuviera formalmente constituida.

En sus inicios, Pluma Libre fue un semanario pequeño, editado a media página -con un total de seis, en formato de folleto- lo que da cuenta de los escasos recursos que tenía. Esto no impedía que su limitada circulación -que no superaba los 1000 o 1500 ejemplares- se desplegara por el sur del departamento de Caldas, el occidente del Tolima y el norte del Valle. Su director y editor, Celimo García Bustamente, se destacó por hacer de este medio un espacio para la defensa de los trabajadores de la región, principalmente, trabajadores agrarios y, en menor medida, de los empleados públicos, por lo cual no vemos en las primeras etapas de este periódico la tendencia obrerista-industrial que tuvo tanta presencia en Unirismo.

Desde su primera etapa (julio-octubre del 33) Pluma Libre pretendió ser, de forma exclusiva, un medio de comunicación político, puesto que no vemos en él secciones noticiosas sobre el acontecer nacional o internacional, pero sí un marcado interés por la comunicación de noticias políticas de carácter regional y local, defendiendo lo que el director denominaba como la "naciente izquierda".

Se trataba, en principio, de la notificación de hechos que estuviesen relacionados o que afectaran los intereses de los "trabajadores". Sin embargo, en los últimos números de la primera etapa, se hizo explícito un marcado interés por defender y divulgar lo que denominaron como "Liberalismo democrático", tendencia política que luego pasaría a ser asociada por este medio con la UNIR (Figura 7). Tal transición ideológica fue producto de los vínculos que García Bustamante tuvo con Gaitán, y al hecho de que, a partir del segundo semestre de 1933, este pasó a ser referenciado como la principal figura política de la recientemente creada UNIR. 


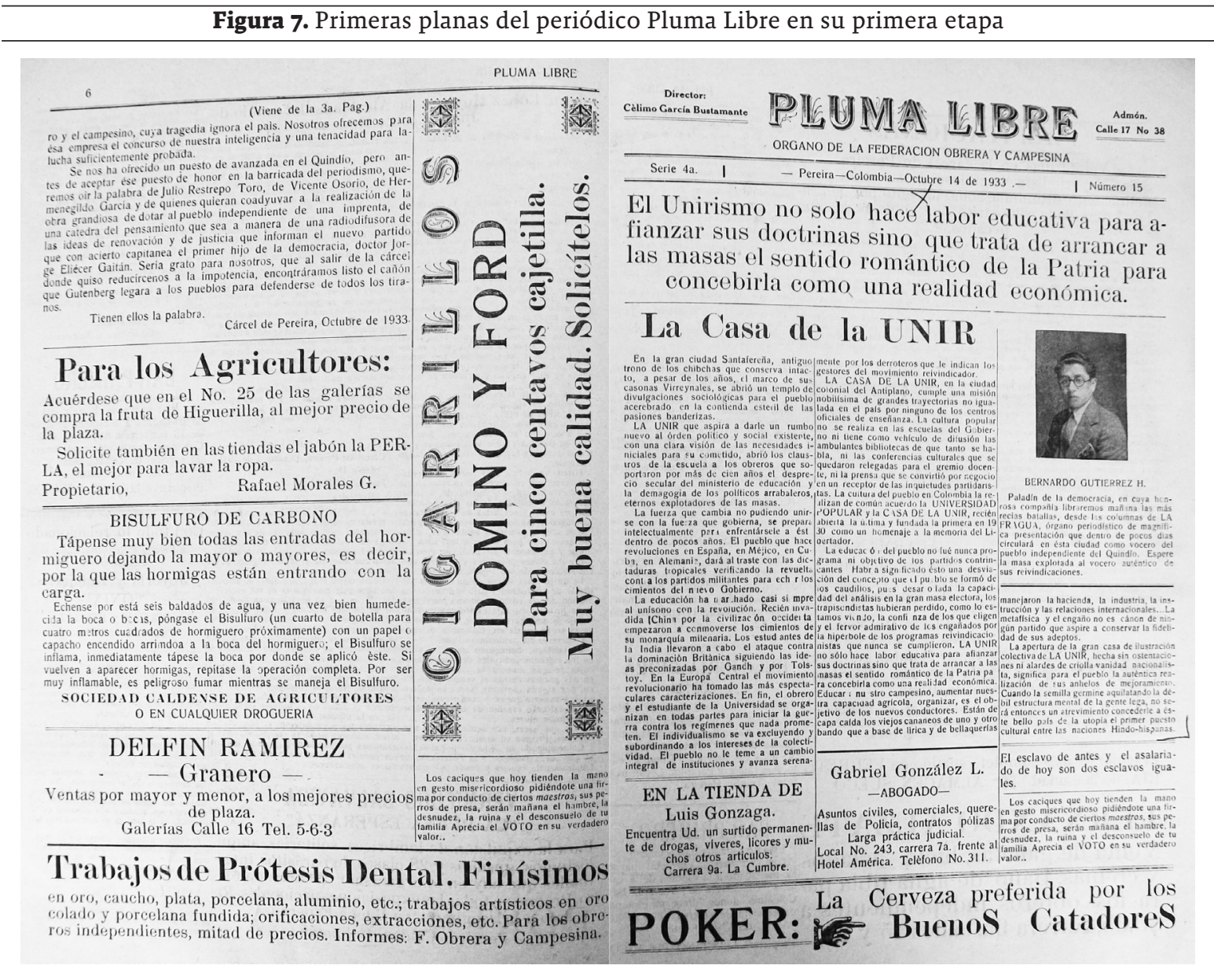

Fuente: Pluma Libre, ediciones de octubre y septiembre de 1933.

Inicialmente, su estructura informativa estaba constituida por cinco columnas fijas: una denominada como "Glosas Liminares" (posteriormente llamada "Semana a semana"), en la que se exponía el hecho político más sobresaliente de la semana transcurrida; otra titulada "Plumadas", dedicada a hacer denuncias políticas; otra denominada como "Los Caneos", en la que se invitaba a un columnista diferente con el fin de tocar algún tema de interés de los "trabajadores"; y una más titulada "Mosaicos", en donde se hacían anuncios y se emitían saludos a campesinos y trabajadores o a líderes locales que expresaban su afinidad con el medio, o bien, donde se presentaba el testimonio de personas que habían sido vulneradas por alguna razón que el periódico consideraba injusta. Con el paso del tiempo, esta sección pasaría a denominarse como "Vida obrera y campesina". De otra parte, hay que señalar que, de modo permanente, existió una editorial que aunque no era firmada por el director del medio, se sobreentendía que García Bustamante era su autor, dado que se advertía que "Todo artículo sin firma pertenece a la Dirección" (Pluma Libre, 15 de julio de 1933, p. 3). Finalmente, de modo intermitente aparecía una sección titulada "Carta Abierta", en la que se le daba el espacio a un lector para hacer algún tipo de denuncia pública o para expresar de manera libre y espontánea sus ideas.

No obstante, a pesar de que la existencia de la UNIR era un hecho muy reciente, y casi simultáneo a la aparición de Pluma Libre, desde sus 
primeros números este medio expresó su admiración por la figura de Jorge Eliécer Gaitán. Ejemplo de ello es el editorial del 26 de agosto de 1933, titulado “Jorge Eliécer Gaitán”, espacio en el que se destacaba y se recibía de buena manera el papel que Gaitán ejercía como parlamentario y como figura política. En palabras del director del medio:

El ingreso al parlamento de este máximo hijo de la democracia colombiana, ha causado singular regocijo en las clases pobres de este país que vemos en su figura estilizada el auténtico vocero de las reivindicaciones proletarias. Asqueado de la política de conciliábulo [...] Y tienen razón, porque en Gaitán no miran al político sino al humanista que quiere hacer Patria para todos y al pergeñador (sic) de un movimiento cuyos ejércitos esperan su voz de mando para centuplicar las actividades y violentar la tradición que luchan por sostener los propagandistas de la metafísica individualista (Pluma Libre, 26 de agosto de 1933, p. 3).

Y a pesar de que contó con el apoyo comercial de la cervecería Póker y de los populares cigarrillos Piel Roja, así como de la promoción de servicios de diferente tipo, mayoritariamente referidos a la comercialización de productos agrícolas, la falta de recursos financieros se manifestaba en los múltiples espacios publicitarios que, al no ser vendidos, eran usados por el director del medio para incentivar la pauta en sus páginas, enganchando a sus lectores con un titular de "AAlarmante!", al que le seguía un texto que indicaba: "Cualquier artículo que Usted desee vender por inservible que sea, llame al 688 , que inmediatamente se trasladará a uno de nuestros empleados para atenderlo".

Adicional a los aprietos económicos que tuvo que sobrellevar desde sus inicios, se encontraban las continuas amenazas y amonestaciones que tenía que padecer García Bustamente, tanto de sus contendores políticos como de las autoridades locales; acciones que condujeron a un prolongado cierre del medio tras los arrestos de los que fue objeto y que mantuvieron inactivo al medio desde finales de octubre de 1933 hasta el sábado 2 de marzo de 1935, reapareciendo con un nuevo aire y orientación.

A partir de la segunda fase (Figura 8), Pluma Libre se convertiría en un medio de comunicación oficialmente adscrito a la UNIR, razón por la cual, al lado de su título, aparecía en rojo y negro el escudo de esa organización, mientras que su subtítulo fue cambiado por el de "Órgano al servicio exclusivo del proletariado colombiano".

Además de estos cambios, en esta nueva etapa, Pluma Libre apareció en formato tabloide a 8 páginas completas, a doble color y con una mayor pauta comercial, por lo cual presumimos que amplió también su tiraje. En la primera página del primer número aparecía la foto de Jorge Eliécer Gaitán y una nota en la que se daba a entender que fue gracias a la intervención de este que sucedió la reaparición del medio, el cual seguiría siendo un semanario hasta su desaparición en diciembre de 1937. Con este conjunto de cambios, Pluma Libre se convertiría en el segundo medio de comunicación unirista luego de Unirismo, expresando su fidelidad ideológica a esa organización hasta que dejó de existir. Desde ese momento, Pluma Libre volvería a ser un periódico sin color y a denominarse como "Semanario socialista, al servicio del proletariado colombiano", combinando sus contenidos entre un discurso marxista y la defensa del liberalismo de izquierda representado por Gaitán.

De todas maneras, independientemente de su relación con la UNIR, lo cierto es que desde su reaparición en marzo del 35 , hasta los primeros tres o cuatro meses de 1936, este medio de comunicación incrementó la difusión de noticias y notas relativas con todo lo que tenía que ver con los trabajadores agrarios adscritos al cultivo del café, pues no hay que olvidar que el periódico se ubicaba en la región que ha sido el epicentro de la economía cafetera colombiana. Y a pesar de los trascendentales cambios ocurridos en la composición interna de la UNIR y del rol político jugado por Gaitán en ella, Pluma Libre sostuvo siempre una buena relación con Gaitán, llegando a difundir una buena imagen de él, aun habiendo transcurrido varios meses desde la fulminante disolución de la UNIR. 
Figura 8. Primera plana de Pluma Libre, segunda etapa

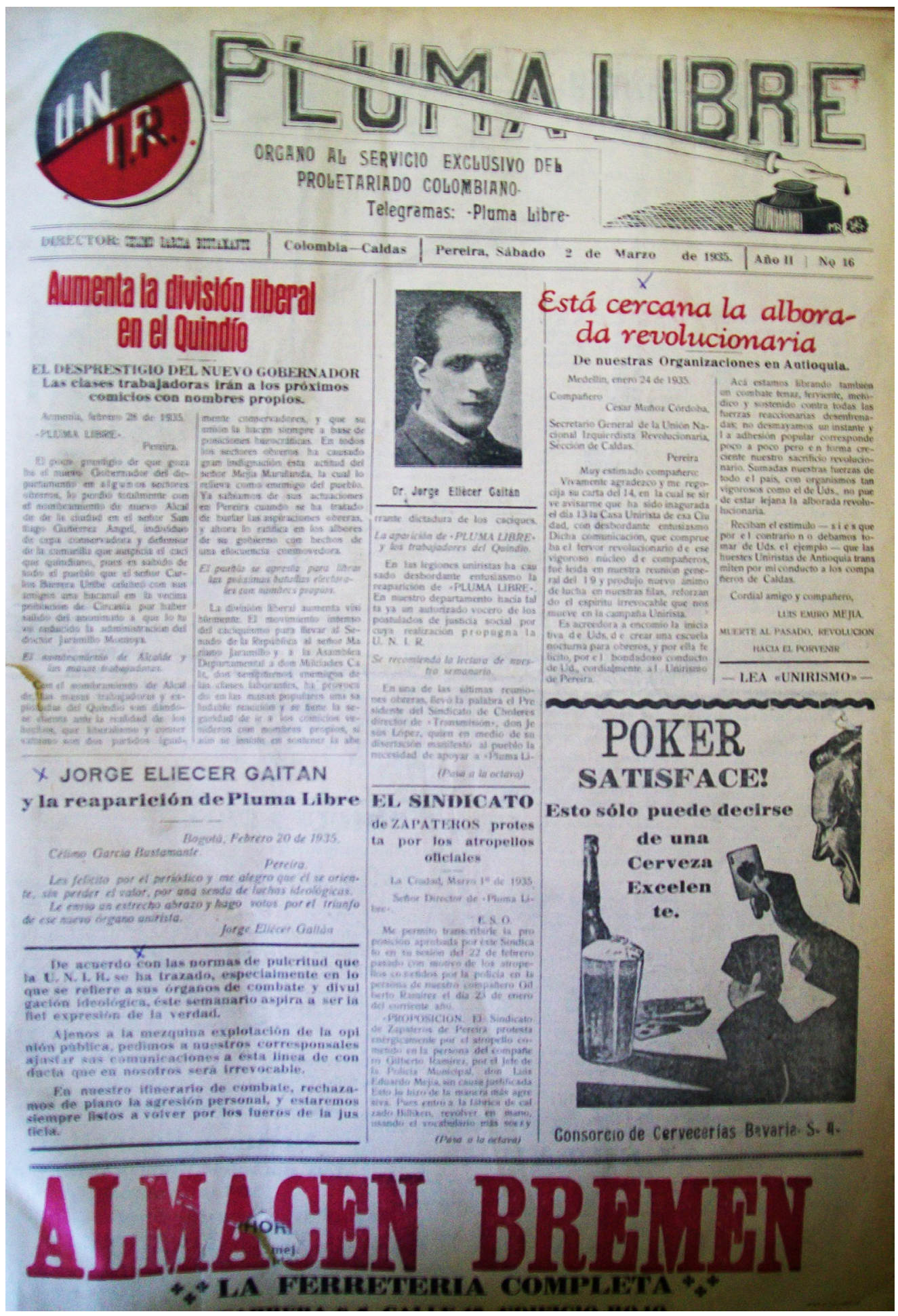

Fuente: Pluma Libre, 2 de marzo de 1935. 
En abril de 1936, por ejemplo, se hizo una férrea defensa de Gaitán, a través de una nota en la que se rechazaba la publicación del libro de Fermín López Giraldo (1937), apodado como el "Sacha" López. En dicho libro se atacaba con descrédito y vehemencia al carismático líder y presidente nacional de la extinta UNIR. En algunos apartes de la nota, dirigida por el director del periódico a López Giraldo, se señalaba que:

Te equivocas cuando afirmas que fue la humilde y oscura vanidad la causa de la desaparición del unirismo como organización política, porque esa enfermedad del alma sólo la padecen las gentes que no han traspasado cierto nivel intelectual que Gaitán ha dejado muy por lo bajo en su ascensión en el conocimiento humano. Pero si no fue la vanidad, porque Gaitán no la padece por no ser un mediocre, la causa eficiente que produjo la cancelación del unirismo, sí lo fue el egocentrismo de su fundador, ya que él le impide a Gaitán tener amplitud cronológica en su lucha por la revolución, de la cual quiere ser el ordenador, el planificador desde el poder. [...] Por otra parte, Jorge Eliércer Gaitán doctrinariamente nunca ha dejado de ser liberal. [....] Pero su liberalismo es al mismo tiempo que un liberalismo racionalista, especulativo, un liberalismo social, basado en el sistema de Augusto Comte. De ahí que hubiera escrito para la UNIR una plataforma que podía tomarse -y se tomó- por una plataforma socialista de acción inmediata, que bien puede realizar, no ya como plataforma sino como programa, un gobierno liberal democrático o de transición. Ahora comprendo por qué Gaitán decía frecuentemente que la lucha unirista tendía a evitar que el liberalismo se conservatizase en el poder (Pluma Libre, 18 de abril de 1936, p. 3).

Por su parte, la nueva estructura temática del medio daba cuenta de un conjunto de intencionalidades mucho más específicas que las cuatro o cinco secciones que caracterizaron la primera etapa de Pluma Libre. Para este momento, si bien se mantiene la sección dedicada a la noticia más destacada de la semana que se presentaba en la primera página, se crea el editorial como columna fija. Adicional a esto, se crean otras secciones fijas mucho más específicas, que dan cuenta de la orientación del medio, con una sección de "Sociales", otra titulada "Página agrícola", otra de crítica y sátira política titulada "Apuntes", y una última titulada como "Ecos de los Campos", en donde se reportaba la adhesión de campesinos u organizaciones campesinas de diferentes municipios de la región circundante, tales como Armenia, Quimbaya, Santa Rosa de Cabal y hasta Cartago (Valle).

Como temas recurrentes de esta segunda etapa se encuentra la disputa interna entre lo que los editorialistas del medio denominaban como los "liberales conservadores" y los "liberales de izquierda", grupo en el que Gaitán y la UNIR eran protagónicos, cumpliendo el papel de ser los "verdaderos" renovadores de dicho partido y de la izquierda colombiana. Además de ello, en las páginas de esta nueva etapa del medio se hizo un importante seguimiento a lo que ellos denominaban como el movimiento de las recogedoras de café, así como a la persecución o el asesinato de algunos líderes liberales de la región, tales como Sebastián Carvajal y Leonardo Muñoz (Pluma Libre, 16 de marzo de 1935, p. 1). Así mismo, las "movidas" políticas de otras organizaciones que consideraban cercanas, tales como la organización de transportadores ferroviarios.

Sin embargo, el grueso de la información emitida tenía que ver con las precarias condiciones de los "trabajadores", palabra con la cual los encargados de Pluma Libre se referían a los campesinos y peones que trabajan en el campo, siendo relevante que no se utilizara, ni de modo frecuente ni como sinónimo, la palabra "obrero". Esto no significaba que tal orientación fuera en desmedro de la idea de mostrarse como parte de una organización como la UNIR, y de mantener informados a sus seguidores de "las movidas" de sus aliados en otras ciudades como Barranquilla o departamentos como el Valle y Antioquia, sobre los cuales se emitían noticias constantemente, dando también una importante cobertura a la asamblea de la UNIR que se llevó a cabo en Bogotá. 
Finalmente, en mayo de 1936, Pluma Libre comenzaría una tercera y última etapa, que duraría hasta finales de 1937, en cuyo subtítulo se indicaba solamente que era un "Semanario socialista" (Figura 9). Por lo tanto, se puede afirmar que este medio de comunicación, durante su trayectoria, abarcó el espectro ideológico que iba desde el sindicalismo obrerista-agrario, pasando por el unirismo, para terminar finalmente en un tipo de socialismo revolucionario. Esta vertiente política se organizaba en torno a la "Vanguardia Socialista" que, según se puede entrever por lo dicho en el periódico, era un ala adscrita a las corrientes izquierdistas del Partido Liberal.

\section{Consideraciones finales}

Los análisis que han abordado al movimiento gaitanista (Green, 2002; 2003; Pecaut, 2000; 2002; entre otros), han dado poca importancia al papel ejercido por los medios de comunicación que este movimiento agenció en diferentes partes del país, especialmente, en sus etapas constitutivas.

El análisis de los medios de comunicación que hemos abordado, además de dar cuenta de la precariedad organizativa y de difusión que vivieron (mucho más marcada en Pluma Libre que en Unirismo) al tratarse de semanarios con pocos recursos, dieron cuenta a su vez del intrincado panorama que experimentó, en sus fases constitutivas, lo que posteriormente sería conocido como gaitanismo.
De esta manera, se puede apreciar que la prensa denominada aquí como gaitanista de los años 30, se debatía entre ser una prensa "liberal izquierdista", una prensa abiertamente "socialista" o ser una variopinta prensa "revolucionaria", lo cual da cuenta de que aún hacía falta una mayor sincronización ideológica entre los activistas y simpatizantes de dicho movimiento. Es claro, a su vez, que Pluma Libre era un medio que estaba mucho más cercano a las características y estándares de calidad descritos en los trabajos de Archila $(1985 ; 1986 ; 1991)$ y Núñez (2006a; 2006b) de lo que era la prensa obrera. En cambio Unirismo, si bien tenía una clara e innegable orientación política, pretendía a su vez constituirse como un medio de comunicación más informativo.

No obstante, a pesar de sus dificultades y limitaciones, estos medios de comunicación evidenciaron a su vez las estrategias discursivas adoptadas por cada uno como empresarios cognitivos para formar sus respectivos públicos, que obedecieron a intereses y prácticas autónomas e independientes.

Además de evidenciar en sus inicios una declarada función de pedagogía ideológica y un mayor enfoque estratégico en cuanto a la organización electoral, producto de una mayor especialización interna (que se reflejaba, por ejemplo, en la definición de un comité directivo y editorial), así como de un mayor control de recursos (que se veían en una mayor continuidad en las ediciones y en un mayor nivel de pauta comercial), vemos que Unirismo centró su interés en dirigir sus esfuerzos en un público más obrero, urbano

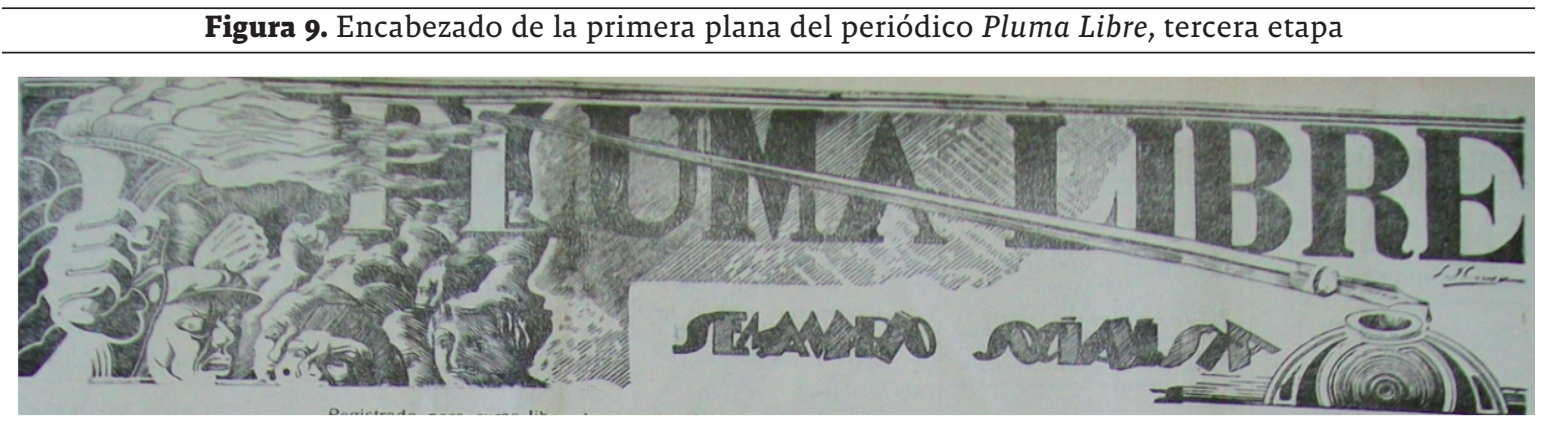

Fuente: Pluma Libre, varias ediciones de 1936. 
e industrial, mientras que Pluma Libre se orientó a unas audiencias mucho más etéreas, de corte campesino o semirural. Esto evidencia una línea editorial inclinada hacia la denuncia de los abusos de poder ejercidos por los patronos en contra de los trabajadores agrarios. Pluma Libre era un medio de comunicación en el que se evidenciaban problemas mucho más severos en la distribución y continuidad de sus ejemplares, con varios cambios en su línea editorial, que se veían reflejados en la orientación o adscripción política dada al medio. Esta se hacía explícita a partir de los subtítulos que García Bustamente le puso al periódico a lo largo de sus tres etapas.

A pesar de ello, ambos medios de comunicación utilizaron de modo recurrente -y a su manerael lenguaje de la lucha de clases, con diferencias que denotaban las dificultades que se tenían para tender puentes más sólidos en lo ideológico y eran producto de las dificultades que representaba salir de sus nichos geográficos o la falta de recursos para mantener una comunicación más fluida entre uno y otro medio de comunicación. Pero no se puede desconocer que las diferencias expuestas entre Unirismo y Pluma Libre aludían a las disimiles condiciones sociales, culturales y políticas que configuraban las audiencias a las que se dirigía cada medio.
A pesar de ello, lo cierto es que la constante alusión a la lucha de clases que existió en estos medios, se constituyó en una estrategia bastante distante de la revolución simbólica que introducirían Jorge Eliécer Gaitán y sus colaboradores a través de los medios de comunicación gaitanistas en la segunda mitad de la década de 1940, al construir una categoría social mucho más impactante, transversal y compleja como lo fue la categoría de "pueblo". Etapa en la que un nuevo medio de comunicación de estirpe gaitanista llegaría a ser considerado como el segundo diario de mayor difusión a nivel nacional, después del influyente periódico El Tiempo, desplazando al también influyente periódico $E l$ Espectador. Hacemos referencia al diario matutino Jornada, que alcanzaría un tiraje superior a los 50000 ejemplares diarios. Época en la que se volvió también frecuente escuchar los discursos de Gaitán por la radio, y en la que el gaitanismo llegaría a cooptar para sus fines al principal partido político del momento, llegando a hacer que su principal líder y referente simbólico fuera considerado como el virtual presidente de la República. Estos elementos dan cuenta del crecimiento y evolución que tuvo el gaitanismo como movimiento social y político, a los cuales se ha hecho referencia en otros lugares (Charry, 2011; 2014).

\section{Referencias bibliográficas}

Archila, M. (1985). La Humanidad, el periódico obrero de los años veinte. Boletín cultural y bibliográfico, 3(22), 19-33.

Archila, M. (1986). La otra opinión: la prensa obrera en Colombia 1920-1934. Anuario colombiano de historia social y de la cultura, (13/14), 209-237.

Archila, M. (1991). Cultura e identidad obrera. Colombia 1910-1945. Bogotá, Colombia: CINEP.

Borrat, H. (1989). El periódico como actor político. Barcelona, España: Gustavo Gili.

Botero, S. (2006). La reforma constitucional de 1936, el Estado y las políticas sociales en Colombia. Anuario Colombiano de Historia Social y de la Cultura, (33), 85-109.

Charry, C. (2011). Entre el público y el movimiento, entre la acción colectiva y la opinión pública. Reflexiones en torno al movimiento gaitanista. Revista de Estudios Sociales, (41), 56-71.

Charry, C. (2014). Jornada. El periódico gaitanista de gran formato. Una aproximación a los cambios de los repertorios de acción de un movimiento social. En J. F. Sánchez (comp.), Miradas impresas. La sociedad colombiana vista desde la prensa (pp. 61-106). Cali, Colombia: Universidad del Valle. 
Unirismo y Pluma Libre. Expresiones y transformaciones de la prensa gaitanista de los años 30

Chicharro, M. y Rueda, J. (2005). Imágenes y palabras. Medios de comunicación y públicos contemporáneos. Madrid, España: CIS.

Gamson, W. y Wolfsfeld, G. (1993). Movements and Media as Interacting System. The Annals of the American Academy of Political and Social Sciences, (528), 114-125. https://doi.org/10.1177/0002716293528001009

Green, J. (2002). Días de emoción espectacular: choque cultural, intrigas políticas y la huelga de choferes de Bogotá en 1937. Historia Crítica, (24), 27-48. https://doi.org/10.7440/histcrit24.2002.02

Green, J. (2003). Gaitanismo, Left Liberalism, and popular Mobilization in Colombia. Tallahassee, US: UPF.

Grossi, G. (2007). La opinión pública. Teoría del campo demoscópico. Madrid, España: CIS.

Kriesi, H. (1999). La estructura organizacional de los nuevos movimientos sociales en su contexto político. En D. McAdam, J. McCarthy y M. Zald (Eds.), Movimientos sociales: perspectivas comparadas (pp. 221-261). Madrid, España: Istmo.

López, F. (1937). El apóstol desnudo. Dos años al lado de un mito. Manizales, Colombia: Ediciones Arturo Zapata.

McCombs, M. (2006). Estableciendo la agenda: el impacto de los medios en la opinión pública y en el conocimiento. Barcelona, España: Paidós.

Monzón, C. (1996). Opinión pública, comunicación y política. La formación del espacio público. Madrid, España: Técnos.

Neveu, E. (2006). Sociología de los movimientos sociales. Barcelona, España: Hacer.

Núñez, L. (2006a). Imágenes y símbolos en la prensa obrera colombiana de las primeras décadas del siglo XX: un análisis de la iconografía popular. Anuario colombiano de historia social y de la cultura, (33), 61-83.

Núñez, L. (2006b). El obrero ilustrado. Prensa obrera y popular en Colombia. 1909-1929. Bogotá, Colombia: Universidad de Los Andes.

Pecaut, D. (1973). Política y sindicalismo en Colombia. Bogotá, Colombia: La Carreta.

Pecaut, D. (2000). Populismo imposible y violencia. El caso colombiano. Revista de Estudios Políticos, (16), 45-70.

Pecaut, D. (2002). Orden y violencia. Evolución socio-política de Colombia entre 1930 y 1953. Bogotá, Colombia: Norma.

Pecourt, J. (2008). Los intelectuales y la transición política. Un estudio del campo de las revistas políticas en España. Madrid, España: CIS

Price, V. (1995). La opinión pública. Esfera pública y comunicación. Barcelona, España: Paidós.

Robinson, C. (1976). El Movimiento Gaitanista en Colombia. Bogotá, Colombia: Tercer Mundo Editores.

Ruíz, J. (2009). Análisis sociológico del discurso: métodos y lógicas. Forum: Quialitative Social Research, 10(2), Art. 26. http://nbn-resolving.de/urn:nbn:de:0114-fqs0902263

Tarde, G. (1986). La opinión y la multitud. Madrid, España: Taurus.

Tarrow, S. (2004). El poder en movimiento. Los movimientos sociales, la acción colectiva y la política. Madrid, España: Alianza Editorial.

Thompson, J. B. (2006). Ideología y cultura moderna. Teoría crítica social en la era de la comunicación de masas. Ciudad de México, México: UAM. 
Thompson, J. B. (2007). Los media y la modernidad. Una teoría de los medios de comunicación. Barcelona, España: Paidós.

Tirado, A. (1981). Aspectos políticos del primer gobierno de Alfonso López Pumarejo 1934-1938. Bogotá, Colombia: Instituto Colombiano de Cultura.

Van Dijk, T. (1990). La noticia como discurso. Barcelona, España: Paidós.

Van Dijk, T. (1997). Racismo y análisis crítico de los medios. Barcelona, España: Paidós. 